\title{
Cost in high impact journals: The problem for researchers from low and middle income countries
}

\author{
Gupta A. ${ }^{1 *}$, Reddy B V. ${ }^{2}$, Kumar Solanki H. ${ }^{3}$ \\ DOI: https://doi.org/10.17511/ijphr.2018.i1.06 \\ 1* Arti Gupta, Assistant Professor, Department of Community Medicine, Veer Chandra Singh Garhwali Government Medical Sciences and \\ Research Institute, Srinagar, Uttarakhand, India. \\ 2 Venkatashiva Reddy B, Assistant Professor, Department of Community Medicine, Veer Chandra Singh Garhwali Government Medical \\ Sciences and Research Institute, Srinagar, Uttarakhand, India. \\ 3 Hariom Kumar Solanki, Assistant Professor, Department of Community Medicine, Government Medical College, Haldwani, Uttarakhand, \\ India.
}

Introduction: Research publication is an important means of career progression for young professionals. At many universities, it is a mandatory requirement to publish a certain number of research paper for raise, promotion, or even recruitment. Today wider acceptance of the open access model has increasingly shifted the cost of publication from the reader to the researcher. The present study aims to study the processing and publication, pricing of index journals. Method: This was anobservational study, studying journals indexed in one of the freely indexing services. We retrieved list of all journals indexed in PubMed between June and December 2015 from the website. We non randomly selected 150 of these for further evaluation study. The outcome measure was publication cost, and pre-processing cost. We retrieved cost related to publication and publication site of the journal from the official website of these selected journals. Results: Out of 5623 indexed journals in PubMed as of July 2015, 150 journals were included in the study. A total of 33 journals was excluded, remaining 117 journals formed the final sample size of this study. Nearly $80 \%$ of the journals had publication cost. The median cost of publication of a typical paper was 2590 US\$. Conclusion: Though the cost of publication was not uniformly high, the average cost was relatively high for researchers in low and middle-incomecountries. It could be as much as one-month's salary of these professionals. This could be a hindrance for publishing research and in the career advancement of these researchers

Keywords: Cost, Publication, Researcher, Low income countries, Research, Middle income countries, Fee charge

Corresponding Author

Arti Gupta, Assistant Professor, Department of Community Medicine, Veer Chandra Singh Garhwali Government Medical Sciences and Research Institute, Srinagar, Uttarakhand, India.

Email: guptaarti2003@gmail.com
How to Cite this Article

Gupta A, Reddy BV, Solanki HK. Cost in high impact journals: The problem for researchers from low and middle income countries. Public Health Rev Int J Public Health Res. 2018;5(1):45-49.

Available From

https://publichealth.medresearch.in/index.php/ijphr/ article/view/80
To Browse

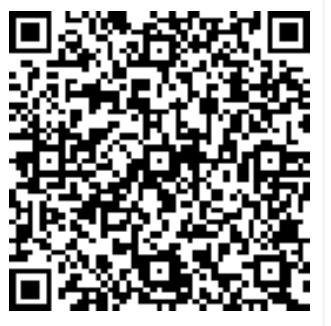

Manuscript Received 2018-03-10

Conflict of Interest No
Review Round 1 2018-03-20

Funding $\mathrm{Nil}$

Review Round 2
2018-03-26
Ethical Approval
Yes

Review Round 2

Yes
Review Round 3

Plagiarism X-checker $8 \%$
Accepted 2018-03-31

(C) 2018 by Arti Gupta, Venkatashiva Reddy B, Hariom Kumar Solanki and Published by Siddharth Health Research and Social Welfare Society. This is an Open Access article licensed under a Creative Commons Attribution 4.0 International License https://creativecommons.org/licenses/by/4.0/ unported [CC BY 4.0]. 


\section{Introduction}

The scholar fraternity in mid 20th century recognized the importance of research paper [1]. Presently researchers worldwide find themselves under increasing pressure to publish or perish [2]. Researchers struggle to publish in international English language journals, that are included in globally respected indexes such as the PubMed [3]. The pressure to publish in English-language journals has increased even for scholars in non-English medium academic environments [1].

The cost of publication plays a key role in deciding publication choices of authors. Tied to high costs of journals is acceptance rate [4]. High impact journals are over burdened by submissions and many of them accept as little as 10 percent of papers, and in some cases even less [5]. The published research is the corner stone for career growth of researchers. New researchers often face difficulty in getting their work accepted by high impact journals [6].

Universities increasingly demand more publications for promotion, salary increases, or retention [7]. The present academic publishing system obstructs the free communication of research findings [8]. By erecting pay walls, commercial publishers prevent scientists from publishing research papers unless they pay substantial fees [9]. The publication cost in indexed journal, is hurdle experienced by most young researcher, particularly of developing countries [10]. The present study aims to study the processing and publication pricing of index journals.

\section{Material and Methods}

Study type: The present observational study was conducted from June - December 2015.

Sample collection: The authors used Google scholar to prepare list of various freely available indexing servicesfor medical science [Index Copernicus, HubMed, Go PubMed, Google Scholar, PubMed, Microsoft academic research, Worldwide Science, Mendeley, Directory of Open Access Journals, POPLINE, Pub Psych, Retina medical search, Russian Science Citation Index, Sci ELO, Science Open, Scientillion] [11,12].

One of the indexing services PubMed, was randomly selected using lottery method to study the journals indexed, PubMed was started in 1996 as a free archive of biomedical and life sciences journal articles.
The sample for the study was drawn from the publicly available PubMed indexed journals [13]. A total of 150 journals were non randomly sampled to study the publication pricing [14]. The website of each journal was studied for publication cost. Where charges were applicable on an original research, an article length of 15 pages was assumed, based on our assessment of a typical article length [15].

Exclusion criteria: The journals were excluded from analysis if it was not in English language, non index Medicus, or no information on cost was available.

Statistical Analysis: Data were entered in Microsoft excel spreadsheet and analyzed with SPSS version 17.0 (IBM Corp., IBM SPSS Statistics for Windows, Version 17.0, Chicago, IL, USA). The results were presented in numbers and proportion. The outcome measure was publication cost, and pre-processing cost. For this study, we considered cost in US dollar terms as of October 2015. Other co-variate studied was the place of publication of the sampled journals.

\section{Results}

A total of 43,938 journals were currently cited [16] and 5623 indexed [17] in PubMed as of July 2015. A total of 150 journals were sampled. Before analysis, a number of journals were excluded: Non Index Medicus Journal (2), Website links not available (17), that not in English language (6), and those whose price information was not available (9).

Of the total 117 studied journals, 103 (88.0\%) charged publication fee and $3.4 \%$ charged pre processing publication fee. Among journals which cost publication charges more than three fourth of the journals were published from the developed world like United States of America (USA) (53.4\%), European region (12.6\%) and United Kingdom (23.3\%).

The publication costs primarily address article processing charges, which includes peer review, editing, proofreading, typesetting, graphics; quality assurance. It also covers other costs like that of the cover, indexing and editorial; rights management, sales and payments; printing and delivery: online user management; marketing and communications: helpdesk; and online hosting. The cost of the ejournal were generally less than the print versions [18]. Over $80 \%$ journals had processing cost of US\$ 1000 and more. 
The median cost in US\$ under different heads in the process of publication was processing charges 2590 [Interquartile range 1775], and pre-processing charges 650 [Interquartile range 4991.7]

Nearly one tenth of the journals in the present study provided an automatic waiver of Article Processing Charges to authors based on any of the countries identified as Low-income economies or Lowermiddle-income economies as classified by the World Bank. Moreover, in other exceptional cases the publication cost is waived off at times, nevertheless this depends on the individual journal discretion.

\section{Discussion}

The present study found that not all journals were that costly, but the average cost was high. The cost is a relative concept, varying from one country to another. The cost, which might be considered high in one setup, may be acceptable for another [19].

Researchers have found that an article that costs US\$ 5,000 to publish in one journal, might cost just less than half to publish in another where as others, which might publish an unlimited, number of articles for onetime payment only [18]. Data from the other studies, suggest that the science-publishing industry has a profit margin of $20-30 \%$ [15]. The true costs that publishers incur in producing their journals are not widely known[15].

The variance in prices makes researchers question how to use scant resources on publishing. The low and middleincome countries, researchers routinely eliminate opportunities for publication from consideration based on cost, even before applying or searching for funding $[20,21]$. The trend of rising journal subscription and membership costs creates a hindrance for libraries across various universities. This force institutes to re-strategize and make lesser purchasing of institutional membership.

This is a big problem in countries like India. Due to lack of any specification from the regulatory bodies like Medical Council of India and others, majority of the institutes does not provide the benefit of institutional membership in a journal. The medical institutes have no obligation to do research and publish. It is more of an individual interest or for career progression [22,23].

It is unlikely that open access will solve problems of the researchers.
In an open access model publication costs of an article is paid from an author's research budget, or by their supporting institution, in the form of Article Processing Charges [24]. These Article Processing charges replace subscription charges and allow publishers to make full-text of every published article freely available to all interested readers. Article processing charge poses next hurdle to the authors for getting quality publication. Most funding agencies have a fixed timeline for budgetary spending and due to publication delay; the provision of publication funds in projects is often not utilized. Our study found that the journals from the developed countries are more likely to be indexed. The scientific editing price plays a crucial role. While researchers struggle to afford to publish in indexed journals, the publishers continue to make profit [25]. Another major concern among authors is the rise of predatory publishers that charge publication fees to authors without providing the editorial and publishing services associated with legitimate journals [26].

The present study found that fewer numbers of journals were indexed in PubMed from developing world. Therefore, for young researchers, doctors, students published in PubMed cannot be a primary criterion for explaining (judging) one's ability. Many researchers have stated connections between lack of money and achievement of success. The high cost of publishing hampers innovation, creativity and knowledge generation [27, 28]. The median salary for a research scientist in India is approximately 9073 US\$ annually [29]. Annual income range from $\approx 7692$ US\$ of beginner to $\approx 13846$ US\$ if they have more than 10 years' experience in career[29]. The cost of publication on an average amounts to be a month's salary for a young researcher. The major limitation of the study was that the present study assessed only one database. The sample studied was small due to logistic reasons. Despite of these limitations, the major strength of the study is its uniqueness. It is first of its kind assessing the cost and place of publication for journals indexed in any database. On intensive online literature search there was lack of similar articles.

\section{Conclusion and Recommendations}

In any major scientific field, it is notion that success depends on getting your articles published in highimpact journals. 
The conclusion that can be drawn from the present study is that high cost is a hindrance for the quality of researcher publication for young researchers. Given that too few reputed indexed journals or other channels exist to accommodate all the articles written, the cost plays a key role. Publications in high impact factor journals or particular indexing cannot be the defining tool to measure success.

The governments can play a key role in boosting access to publications to bring equity for researchers from central institutes, state government institutes, and private sector. The publicly funded research should be published such that it is freely available to everyone. Institutions /organizations should value funding models that promote universal access to their research output. E-journals should be weighted equal to that of print. Provision of financial aid of and making Institutional membership compulsory for a minimum number of journals or reimbursement to the employees for a minimum set criteria can promote research from all institutes across India.

\section{New knowledge}

This study highlights the fact the publication in high impact journals by individuals in developing countries should not be the only major criteria for assessing competency.

\section{Contribution of authors}

AG designed the study and prepared the first draft. AG, VB and HS collected and analyzed the data. All the authors provided critical inputs into the paper. AG approved the final draft. Authors declare the manuscript has been read and approved by all the authors, that the requirements for authorship as stated earlier in this document have been met, and that each author believes that the manuscript represents honest work, if that information is not provided in another form.

\section{Acknowledgement}

The authors would like to thank Dr. Anand Krishnan, for his most support and guidance.

\section{Reference}

01. Altbach PG, Rapple B. Anarchy and Commercialism. 2012 Mar.

Available from: [Article] [Crossref]
02. Pesce R. What can Healthcare Providers do?. 2013 Apr. Available from [Article] [Crossref]

03. Davis PM, Walters WH. The impact of free access to the scientific literature- a review of recent research. J Med Libr Assoc. 2011 Jul;99(3)208-17.

doi: 10.3163/1536-5050.99.3.008 [Crossref]

04. Naughton J. Academic publishing doesn't add up. 2012 April.

Available from: [Article] [Crossref]

05. Odlyzko AM. Open access, library and publisher competition, and the evolution of general commerce. Eval Rev. 2015 Feb;39(1)130-63.

doi: 10.1177/ 0193841X 13514751. Epub 2014 Apr 2 [Crossref]

06. Butler D. Investigating journals- The dark side of publishing. Nature. 2013 Mar 28;495(7442)433-5. doi: $10.1038 / 495433 a$ [Crossref]

07. Bynner J, Goldstein H. Open access publishing should not favour those with deep pockets. 2012 May.

Available from: [Article] [Crossref]

08. Blow NS. The many challenges of open access. Biotechniques. 2011 Nov;51(5)291.

doi: 10.2144/ 000113755 [Crossref]

09. T Bergstrom and CT Bergstrom. Can 'author pays' journals compete with 'reader pays'?. Nature. 2004.

Available from: [Article] [Crossref]

10. Saxena S, Sharan P, Saraceno B. Research for Change- the role of scientific journals publishing mental health research. World Psychiatry. $2004 ; 3(2) 66-72$.

[Crossref]

11. List of academic databases and search engines. Available from: [Article] [Crossref]

12. Dhammi IK, Haq RU. What is indexing. Indian J Orthop. 2016 Mar-Apr;50(2)115-6. doi: $10.4103 / 0019-5413.177579$ [Crossref] 
13. A Fact Sheet MEDLINE, PubMed, and PMC (PubMed Central)- How are they different?. Available from: [Article] [Crossref]

14. NLM Catalog.

Available from: [Article] [Crossref]

15. Corbyn Z. Price doesn't always buy prestige in open access. Nature. 2013 Jan.

Available from: [Article] [Crossref]

16. List of All Journals Cited in PubMed. Available from https://www. nlm. nih.

gov/bsd/serfile_addedinfo.html [Crossref]

17. Number of Titles Currently Indexed for Index Medicus and MEDLINE on PubMed.

Available from: [Article] [Crossref]

18. Van Noorden R. Open access- The true cost of science publishing. Nature. 2013 Mar 28;495(7442)426-9.

doi: $10.1038 / 495426 a$ [Crossref]

19. Academic publishing doesn't add up. Available from: [Article] [Crossref]

20. White House Task Force on Middle Class Families STAFF REPORT: Barriers to Higher Education. Available from: [Article] [Crossref]

21. Paton C, Househ M, Malik M. The challenges of publishing on health informatics in developing countries. Appl Clin Inform. 2013;Sep $11 ; 4(3) 428-33$.

doi: 10.4338/ACI-2013-04-IE-0030. eCollection2013

[Crossref]
22. Eckman CD, Weil BT. Institutional open access funds- now is the time. PLoS Biol. 2010; May 25;8 (5)e1000375.

doi: 10.1371/journal.pbio.1000375 [Crossref]

23. Sample I. Harvard University says it can't afford journal publishers' prices. 2012 Apr.

Available from: [Article] [Crossref]

24. Sills ES, Vincent TT, Palermo GD. Article processing charges, funding, and open access publishing at Journal of Experimental \& Clinical Assisted Reproduction. J Exp Clin Assist Reprod. 2005 Jan13;2(1)1.

[Crossref]

25. The Problem- Students can't access essential research.

Available from: [Article] [Crossref]

26. Shen C, Björk BC. 'Predatory' open access- a longitudinal study of article volumes and market characteristics. BMC Med. 2015 Oct 1;13;230.

doi: 10.1186/s12916-015-0469-2 [Crossref]

27. Poverty key hindrance to student success, study shows.

Available from: [Artricle] [Crossref]

28. Pushkar. The Challenges of Publishing As An Indian Academic. Jan 2014.

Available from: [Article] [Crossref]

29. Research Scientist salary (India). Available from: [Article] [Crossref] 